\title{
Desecuritization as Displacement of Controversy: geopolitics, law and sovereign rights in the Arctic
}

Marc Jacobsen, PhD Candidate, Centre for Advanced Security Theory, Department of Political Science, University of Copenhagen

Jeppe Strandsbjerg, Associate Professor, Department of Business and Politics, Copenhagen Business School

This article suggests that the Ilulissat Declaration of 2008 can be perceived as a preemptive desecuritization act in reaction to the growing concern for military conflict in the wake of the Russian flag planting on the North Pole in 2007. The declaration confirmed that science and international law shall determine the delineation of the Arctic Ocean. However, while it was successful in silencing securitization attempts, the shift from security to science and law generated new dilemmas and controversies: within international law there has been controversy over its ontological foundations and within science we have seen controversy over specific standards, hence challenging the notion of 'normal politics'. While minimizing the horizontal conflict potential between states, this development has simultaneously given way for vertical disputes between the signatory states on the one hand and the Indigenous peoples of the Arctic on the other.

Introduction $^{1}$

In May 2008, the five states adjacent to the Arctic Ocean, the so-called Arctic Five (A5), signed the Ilulissat Declaration. In the Declaration, they declared their shared intention to cooperate and settle the allocation of sovereign rights in the Arctic Ocean on the basis of international law and scientifically valid geodata. The declaration was, as we will explain, a reaction to a growing concern among scholars and politicians reacting

\footnotetext{
${ }^{1}$ We would like to thank our fellow colleagues whose critique, suggestions, and encouragements have been invaluable in the development of this paper. The theoretical argument benefitted greatly from a work-in-progress seminar hosted by Centre for Advanced Security Studies, while the empirical details were enhanced following an Arctic Politics Research Seminar at University of Copenhagen. Ulrik Pram Gad, Michael Byers and the anonymous reviewer deserve special thanks for their thorough and thoughtful comments which were decisive in the final stages of writing.
} 
in particular to media reports on the potential for conflict and an increasing militarization of the Arctic region. More specifically, the concern arose over the distribution of sovereign rights to what is called the Outer Continental Shelf in the Arctic Ocean. As such, we suggest, the Ilulissat Declaration was an act of pre-emptive desecuritization initiated by state elites to prevent a securitized Arctic scenario. To the extent that the Ilulissat Declaration became a standard reference in subsequent scholarly and political conversations, including academic publishing, about the legal status of the Arctic, the declaration has been effective because it has become a powerful argument for why Arctic geopolitics is not about to become securitized. However, in this article we are not only concerned with Arctic geopolitics but, more specifically, we aim to show how the Ilulissat Declaration, as an act of pre-emptive desecuritization, can teach us something about how desecuritization also works. We suggest that desecuritization is not necessarily about moving a policy issue from security back to normal politics but, rather, desecuritization works by shifting a policy issue from one technique of government to another. This shift, we argue, entails a displacement of a controversy, meaning that the shift generates new controversies arising from the issue being desecuritized.

In its original formulation by scholars associated with what has come to be known as the Copenhagen School, desecuritization was referred to as an opposite process of securitization; i.e. attempts to prevent a policy issue from being securitized or attempts to move issues from the realm of security and back to normal politics (Wæver 1995, 57-58). The initial writings were about how desecuritization could be achieved (Huysmans 1995; Wæver 2000), as it was perceived to represent a positive move reclaiming an issue from the exceptional realm of security back to the normal realm of politics. Later, this view of desecuritization became criticized for avoiding politics (Aradau 2004) and for not being morally superior to securitization (Floyd 2011). Others have sought to recover and highlight the political richness of the concept through examining its ontological and practical levels (Hansen 2012). Analyses of desecuritization have subsequently followed three strands of questions: (1) what counts as desecuritization; (2) why desecuritization should take place; and (3) how it may be achieved (Balzacq, Depauw, and Léonard 2015 cf. Bourbeau and Vuori 2015, 254). The issue of migration has been a particularly popular case in these studies (Roe 2004; Huysmans 1998; Huysmans 2006). Usually, desecuritization has been analyzed as a post hoc process taking place when something has already been securitized, but as Philippe Bourbeau and Juha A. Vuori (2015) argue - as they take up the cue from some of the earliest studies of desecuritization (Wæver 1989; 1995; 2000) - desecuritization may be a preemptive act made in order to prevent the securitization of a particular referent object.

Analyzing the Ilulissat Declaration as a pre-emptive desecuritization act is interesting for a number of reasons. First, the Ilulissat Declaration was largely driven by state elites with the aim of avoiding a security scenario articulated by members of a broader public. Conventionally, analyses of desecuritization posit state elites as those who securitize, and public voices - for lack of a better term - as those who seek to desecuritize. Second, and this is the most significant for this article, the success of the 
Ilulissat Declaration was built on its ability to shift the question of sovereign rights from a potentially securitized domain to another, very particular legal-technical regime codified by the United Nations Convention on the Law of the Sea (UNCLOS). The point here is that while avoiding the spectre of security, such a shift from security to law and science is not necessarily a return to a more democratic and open political domain but rather another institutional domain governed by its own rules and logics. We label these domains as different techniques of government.

The main purpose of this article is to show how such acts of desecuritization through shifting techniques of government may generate new lines of controversy. While this shift has, indeed, been successful in minimizing the risk of horizontal conflict between states, it has simultaneously given way for vertical disputes between the signatory states on the one hand and the Indigenous peoples of the Arctic on the other who question the very ontological foundation of the sovereignty concept and the legitimacy behind the alleged right to delineate the Arctic. If peaceful status quo persists, such voices will probably continue to be audible, but if the involved states are not satisfied with the resolution of their overlapping claims, hardened interstate rhetoric and securitization attempts may resurface. As such, desecuritization is contingent. In what follows, we will briefly present the theoretical notion of desecuritization, followed by an outline of the historical geo-strategic concerns in the Arctic. This again is followed by an analysis of the Ilulissat Declaration as a case of desecuritization, while finally laying out the displacement of controversy.

\section{Desecuritization and techniques of government}

The question of what makes something a security issue has traditionally been dealt with in objective terms, in the sense that we could objectively analyze the world to say whether a given phenomenon should be considered a risk. As such the study of security would be concerned with how actors (politicians, bureaucrats, and strategists) would or could best respond to a threat. As a central part of the constructivist turn in International Relations, the Copenhagen School formulated a discursive take on security, famously coining the term securitization (Wæver 1995; Buzan et al. 1998). In contrast to conventional realist (as philosophical realism) understandings of threats being objective facts, the most radical claim by the Copenhagen School is that something becomes a security issue not by virtue of its inherent nature but through discursive statements. Drawing on language theory, Ole Wæver posits security as a speech act where it is the utterance, designating something as a security issue in itself, that is of interest rather than the referent of that utterance (Wæver 1995, 55). This in turn transfers the security focus of studies from the objective needs and threats surrounding a state/society to the realm of political discourse.

The next important step is that security and insecurity do not represent a binary opposition. Rather, the opposite of security is desecurity, with desecurity meaning normal politics. An agenda of minimizing security cannot move forward by criticizing se- 
curity, rather, it must understand the language-game that security is (Wæver 1995, 56). Rejecting the binary nature of in/security, Wæver removes the positive connotations surrounding the concept of security. By insisting that the counter to security is normal politics, it follows that a democratic ethos would pursue an agenda of desecuritization in order to deal with politics through normal procedures. The logic behind this is that because security as a concept signifies existential threats to a particular state or political order, then issues of security are dealt with through emergency laws and exceptional measures not encompassed by normal democratic rules of transparency and accountability. As a language game, security "is articulated only from a specific place, in an institutional voice, by elites" (Wæver 1995, 57). Buzan, Wæver, and de Wilde operate with a continuum ranging from non-politicized (meaning something is not an issue for public policy) over (normal) politicized to securitized (exceptional measures) (Buzan et al. 1998, 23-24).

The most obvious way to desecuritize is to not talk about issues in terms of security, but to ignore securitization and insist that an issue is non-politics or normal politics. In cases where something is already securitized, this is not a viable strategy. It is then necessary to put things back into normal politics (Huysmans 1995, 65; Roe 2004, 284). The second way is to actively downgrade the issue by redefining it as not being a threat towards a valued referent object (Buzan and Wæver 2003, 489). Third, and most common, is the indirect discursive process of redirecting the security discourse towards other more compelling issues that are securitized at the expense of the first issue that, more or less unnoticed, is reduced to the discursive level of politics (Buzan and Wæver 2003 , 489). These ways can follow objectivist, constructivist, or deconstructivist routes to desecuritization (Huysmans 1995, 65-67). As we will discuss, the kind of desecuritization in the Arctic today is an elite-driven, pre-emptive desecuritization following the second logic. We see state representatives continuously arguing that there is little tension, plenty of cooperation, and little to worry about in Arctic interstate relations.

There is an on-going sentiment in the writings dealt with here that to desecuritize is to render issues more democratic and accountable because they avoid the emergency rules associated with security: "to desecuritize surely implies exactly that - to take security out of security, to move it back to normal politics" (Roe 2004, 285). In that sense, normal politics is better than security. The aim to return to normal politics posits a challenge to the more conventional view that security is good because it avoids insecurity. However, it has also led to a debate of the definition of normal politics. Is it democratic? What are normal rules and procedures? From a Foucauldian perspective, it is obvious to question the notion of normality. In the Arctic context, the debate of what 'normal' politics is should also remain an open question. Within this larger debate, the aim of this article is to demonstrate how normalization meant shifting the issue of sovereign rights delineation into other socio-political domains or techniques of government. In its wording, the Ilulissat Declaration shifted questions of sovereignty into a combined legal and scientific-technical domain by pointing to an existing legal framework and 
diplomatic practice for dealing with such issues and not to a general field of 'normal politics'.

The following analysis suggests that desecuritization in this case is not a question of stepping back from security into an arena of normal politics. Rather, it is meant to shift a policy issue into another technique of government. As such, successful desecuritization might require the existence of alternative institutional frameworks capable of handling this issue. These other frameworks will embody different kinds of controversies compared to those of security. And while a desecuritization act obviously aims to move an issue out of the emergency, the move will not remove but rather displace controversies. The next part briefly outlines the historic Arctic security discourse from a securitization point of view. This will be followed by the analysis of the Ilulissat Declaration as a desecuritizing act through replacement of one policy issue to other government techniques.

Geostrategic concerns in the Arctic: the spectre of security in a historic perspective

During the Cold War, the Arctic was home to significant US and USSR armament in which Thule Air Base and the Kola Peninsula became key strategic military locations. Even though an argument could be made that it was also the theatre of 'normalized' security routines and East West cooperative initiatives, like the A5's Polar Bear Treaty of 1973 (cf. Byers 2013, 173), the then global macrosecuritization ${ }^{2}$ of a possible nuclear war between the Warsaw Pact countries and NATO (Buzan and Wæver 2009) dominated the security discourse in the Arctic region. It was often subject to securitization attempts in relation to the military sector, well exemplified by then U.S. Air Force General Harp Arnold who in 1946 stated that "[i]f there is a third world war [...] its strategic center will be the North Pole" (Murphy 1947, 61 cf. Hough 2013, 25). In response to the antagonistic military rhetoric and the significant military build-up, a couple of unsuccessful desecuritization attempts were made. In 1980, Norway's then Prime Minister Oddvar Nordli proposed a nuclear weapon free-zone in the Arctic (Apple 1980, 17), and six years later, Secretary-General Mikhail Gorbachev and U.S. President Ronald Reagan met in Reykjavik to discuss the possibilities of warming up bilateral relations. None of the initiatives led to the intended result, but they were considerable steps in the desired direction, culminating with Gorbachev's famous Murmansk speech in 1987, in which he stated that "[t]he militarization of this part of the world is assuming threatening dimensions" (Gorbachev 1987, 4) and made clear that "[t]he Soviet Union is in favor of a radical lowering of the level of military confrontation in the region.

\footnotetext{
${ }^{2}$ Securitization theory has mainly focused on the middle level of world politics, so in their aim of applying the concept to what happens above the middle level, Buzan and Wæver introduced the concept of macrosecuritization. In their influential article, the Cold War is highlighted as the example par excellence of an over-arching conflict that "[...] incorporate, align and rank the more parochial securitizations beneath it" $(2009,253)$.
} 
Let the North of the globe, the Arctic, become a zone of peace. Let the North Pole be a pole of peace" (Gorbachev 1987, 4). As Kristian Åtland has rightly shown, this speech served as an desecuritization act, paving the way for normal politics in an Arctic previously characterized by geostrategic concerns (Åtland 2008).

Following the end of the Cold war, the Soviet/Russian Northern Fleet declined, as did security concerns more generally in the region. Disputes over sovereignty were generally contained or localized and not subject to securitization attempts. Over the past fifteen years, global interest in the region has, however, increased for one of three reasons. Overall, climate change is increasing accessibility to the region and, thus, is (1) opening new shipping lanes; (2) catalyzing economic exploitation of hydrocarbon and mineral resources; and (3) highlighting continental shelf claims by Arctic states. Accompanying these developments, Arctic states have redefined and developed Arctic strategies, and several countries have revamped their military capabilities as clear signals that they are ready to defend their interests. As a result, the Arctic has re-emerged as a geostrategic space attracting an increasing amount of political and public attention and resurrected the spectre of geopolitics. Two more or less consecutive events especially fueled the global Arctic interest and drew significant headlines. First, the (in)famous planting of the Russian flag on the geographical North Pole, 4,261 meters below sea level, on August $2^{\text {nd }}, 2007$. Second, the publishing of US Geological Survey's (USGS) estimate of undiscovered oil and gas north of the Arctic Circle suggesting that the "extensive Arctic continental shelves may constitute the geographically largest unexplored prospective area for petroleum remaining on Earth" (USGS 2008, 1). With the incipient financial crisis and historical high oil prices that reached $\$ 100$ per barrel in the beginning of 2008 (Krauss 2008) and peaked in July 2008 with a price of $\$ 147$ a barrel (Hopkins 2008), the publication gained worldwide attention.

It was the combination of the imagination of hitherto unknown riches with the absence of settled sovereignty in the Arctic that paved the way for a variety of conflict scenarios, accelerated by the Russian flag planting organized by leading members of the Putin-loyal party United Russia (Dodds 2015, 380f). The spectacle mirrored, it was thought, European colonial practices of claiming land through symbolic acts in previous centuries and it was, thus, met by unambiguous negative replies from the other Arctic states. Canada's then Foreign Minister Peter MacKay noted "[y]ou can't go around the world these days dropping a flag somewhere. This isn't the $14^{\text {th }}$ or $15^{\text {th }}$ century" (thestar.com 2007). Spokesman of the U.S. Department of State Tom Casey said "I'm not sure whether they've, you know, put a metal flag, a rubber flag, or a bed sheet on the ocean floor. Either way, it doesn't have any legal standing or effect on this claim" (Casey 2007). Russian explorer and Duma member, Arthur Chilingarov, retorted: "I don't give a damn what all these foreign politicians they are saying about this [...] Russia must win. Russia has what it takes to win. The Arctic has always been Russian" (Associated Press 2007).

The event, indeed, caused a hardened rhetoric between the Arctic states, but actual securitization attempts were not made from official state level. Some commentators 
and academics, on the other hand, were quick to point out the dangers of this development, painting a public image of sovereign states participating in an anarchic race for riches and new territory in one of the world's last remaining terra nullius. Headlines such as 'The Arctic Cold War' (Chung 2007), 'Scramble for the Arctic' (Financial Times 2007) and 'Arctic Meltdown' (Borgerson 2008) in non-tabloid media like Toronto Star, Financial Times, and Foreign Affairs, framed an impression of a region riddled with conflict, insecurity, and military threats. In his influential essay, Borgerson warned against 'the coming Arctic anarchy' and argued that "[...] the situation is especially dangerous because there are currently no overarching political or legal structures that can provide for the orderly development of the region or mediate political disagreements over Arctic resources or sea-lanes" (Borgerson 2008, 71), and "[u]ntil such a solution is found, Arctic countries are likely to unilaterally grab as much territory as possible and exert sovereign control over opening sea-lanes wherever they can" (Borgerson 2008, 73-74). In this climate, it took little imagination to picture a scenario where the A5 were racing to secure and defend sovereign rights over assets through flags and guns.

Desecuritization of sovereignty disputes through science and international law

Denmark's then Foreign Minister, Per Stig Møller, took initiative to invite high-level representatives of the so-called A5 to a meeting in Ilulissat, Greenland, in direct response to this hardened interstate rhetoric and the growing mass of news reports outlining potential conflict scenarios in the Arctic. In his own words, he woke up one morning "soaked in perspiration with the head full of Russian submarines" (Breum 2013, 28) and realized that something had to be done. On May $28^{\text {th }}, 2008$, the A5 representatives declared that "the law of the sea provides for important rights and obligations concerning the delineation of the outer limits of the continental shelf, the protection of the marine environment, including ice-covered areas, freedom of navigation, marine scientific research, and other uses of the sea. We remain committed to this legal framework and to the orderly settlement of any possible overlapping claims" (Ilulissat Declaration 2008). The rationale behind the declaration was to de-escalate security concerns and signal to a wider audience that the five states were not about to engage in an Arctic arms race but able to, and did indeed, cooperate on relevant areas. Explicitly referring to the attempts to securitize the Arctic in military terms, Møller concluded the meeting by stating "[...] we have hopefully, once and for all, killed all the myths of 'a race to the North Pole'. The rules are in place. And the five states have now declared that they will abide by them" (Byers 2009, 89).

With that, the A5 also refuted the common perception of the Arctic Ocean as terra nullius, or a legal vacuum, while refusing alternative solutions e.g. following the logic of the Antarctic Treaty that does not recognize any sovereignty claims (Article 4) and bans military activity with non-scientific purposes (Article 1) (ATS.aq). Those, who had previously argued for the security scenario now widely acknowledged the new de- 
velopment. This is well exemplified by Borgerson's Foreign Affairs essay five years later, in which he admitted: "[...] a funny thing happened on the way to Arctic anarchy. Rather than harden positions, the possibility of increased tensions has spurred the countries concerned to work out their differences peacefully. A shared interest in profit has trumped the instinct to compete over territory. Proving the pessimists wrong, the Arctic countries have given up on saber rattling and engaged in various impressive feats of cooperation" (Borgerson 2013, 79). Hence, the declaration was a successful pre-emptive desecuritization act that signaled to the world that no Cold War ghosts were about to resurface in the Arctic, and that the A5 would deal with issues of sovereignty and maritime safety through normal political procedures.

But what are normal political procedures? Much of Arctic sovereignty concerns arose because UNCLOS, concluded in 1982 and adopted in $1994^{3}$, allows states to claim two types of extended zones beyond their territorial sea of maximum 12 nautical miles (NM) from shore: The Exclusive Economic Zone (EEZ) giving rights to the water column and the Continental Shelf (CS), giving rights to the seabed. Both are defined as $200 \mathrm{NM}$ zones ranging from the juridical coastline, and as such the EEZ and the CS are juridical constructs. In cases where the geological continental shelf exceeds beyond the $200 \mathrm{NM}$, states can, moreover, claim an extended Continental Shelf Zone. This claim must be supported by scientifically valid geodata of the seabed in order to prove to the Commission on the Limits on the Continental Shelf (CLCS), established under the auspices of UNCLOS, that the continental shelf extends beyond the $200 \mathrm{NM}$. By turning the question of extending sovereign rights into a question of scientific surveying, the law, in effect, renders normal politics a matter of technology and science.

It is common practice in international law to refer to geographical features when defining limits to sovereignty. The logic of the law assumes that 'nature' provides a unified presence and science represents this with a consensual voice. And yet, science is, in this process, politicized, and science never speaks with an unambiguous voice. This is recognized within international law as well (cf. Shaw 2003, 534). Yet, in response to this politicization of their oeuvre, geo-science holds on to the virtues of truth and objectivity. Responding directly to this question, the leader of the Greenland part of the Continental Shelf Project of the Kingdom of Denmark, Christian Marcussen, stated that scientists will seek to interpret the data in a way that is as beneficial as possible for Extended Continental Shelf claims while staying within what is scientifically credible (Strandsbjerg 2010). Emphasizing the scientific ethos, an editorial in Nature Geoscience stated that "[o]nly if the science that underlies its recommendations stands the test of time will the shelves' outer limits established under UNCLOS be globally respected as

\footnotetext{
${ }^{3}$ The U.S. is the only of the A5 who has not signed and ratified the UNCLOS. Despite a significant internal pressure for a U.S. signature, it has so far been rejected by a group of senators who fear that the same laws could be used against the U.S. in other instances and more generally because they are "[...] fearful of ceding too much sovereignty to a supranational organization [...]" (Ebinger and Zambetakis 2009, 1224). In the 2009 U.S. Arctic Region Policy it is however, mentioned that "The Senate should act favourably on U.S. accession to the U.N. Convention on the Law of the Sea promptly, to protect and advance U.S. interests, including with respect to the Arctic" (Bush 2009, 3).
} 
the one and only valid demarcation line" (Nature Geoscience 2009, 309); i.e. the route to better boundaries is better science.

As an act of desecuritization it, first, came from the political elite to preemptively de-escalate conflict scenarios and, second, it appears that this was done by actively shifting the issue by using other techniques of government, namely law and geo-science. To the extent that desecuritization has been successful, it is because alternative mechanisms existed that could deal with delineation of the continental shelves. It is, of course, difficult to speculate about the conditions in cases where such a framework had not existed. But, in its absence, there would have been no procedures and standards for how to deal with the issue. In effect, it would have been harder for those involved to persuade each other as well as the public that there was no need to worry. As discussed above, the return of an issue to normal politics should be a progressive move leading to a more democratic and transparent handling of security issues. However, the shift from securitization as a technique of government to law and geo-science as new distributive logics are in place. Rather than democracy, the issue is now decided by right and measurement. This might be preferable to a question of survival, but it is not necessarily more democratic. Instead, a return to normal politics might be a question of shifting between different techniques of government - shifts that displace controversies.

\section{Displacement of controversy}

"Sovereignty" is a term that has often been used to refer to the absolute and independent authority of a community or nation both internally and externally. Sovereignty is a contested concept, however, and does not have a fixed meaning. Old ideas of sovereignty are breaking down as different governance models, such as the European Union, evolve. Sovereignties overlap and are frequently divided within federations in creative ways to recognize the right of peoples. For Inuit living within the states of Russia, Canada, the USA and Denmark/Greenland, issues of sovereignty and sovereign rights must be examined and assessed in the context of our long history of struggle to gain recognition and respect as an Arctic indigenous people having the right to exercise self-determination over our lives, territories, cultures and languages." (ICC, 2009: sect. 2.1).

In response to the Ilulissat initiative, the Inuit Circumpolar Council (ICC) issued A Circumpolar Inuit Declaration on Sovereignty in the Arctic, from which the above quote is taken. They reacted against the A5 settling sovereign demarcation without including the concerns of the Inuit, who constitute a well-organized Indigenous group of people in the Arctic. Apart from not being involved in the drafting of the Ilulissat Declaration, the ICC tried - at least rhetorically - to challenge the foundations of international law. As part of the scholarship on a changing understanding of sovereignty, they detach sover- 
eignty from the state and, in effect, made the case for sovereignty referring to a much looser community that may exist across state boundaries (Shadian 2010; Gerhardt 2011). In a similar way, the leader of the Greenlandic party Inuit Ataqatigiit, Sara Olsvig, suggested that Hans Island, or Tartupaluk as it is called in Greenlandic, should be declared 'Inuit Land' as it has been used for hunting by the Inuit since the $14^{\text {th }}$ Century (Inuit Ataqatigiit 2015). Olsvig's suggestion came as a reply to Professor Michael Byers' and Associate Professor Michael Böss' proposal that Hans Island should be turned into a condominium, equally shared and co-managed by Denmark and Canada (Weber 2015). Instead, Olsvig argued, this should be in the hands of Nunavut and Greenland.

We start to see here the contours of a displacement of controversy. By settling the security concerns over sovereign rights among the A5, the Ilulissat process has opened another controversy with the ICC challenging a conventional statist understanding of sovereignty and norms of international control and ownership. As has been discussed in more detail elsewhere, the Inuit claimed a different conceptualization, use, and practice of space than that underwriting law (Strandsbjerg 2011; Strandsbjerg 2012). In spatial terms, international law operates with land and sea as two distinct categories. In this schema, ice counts as water (in hard form) and, thus, as a maritime space. However, for the Inuit ice constitutes a material space used for travel and hunting, and it appears to play a somewhat hybrid role in between the dogmatic distinction between land and maritime space (Joyner 1991). That is, the pre-emptive desecuritization through law has displaced the controversy to one concerning the ontological foundations of international law.

If we turn to the other dimension in the legal-scientific nexus dealing with the continental shelf, there is an obvious immanent controversy arising over the quality of science. This has already been alluded to in the previous section discussing how science deals with their role in distributing sovereignty. CLCS has published guidelines for the validity of data and surveys required in order to make claims to an extended continental shelf zone, but uncertainty remains as to what exactly constitutes good enough data (Macnab 2008). Scientist and cartographic technocrats always play a key role in International Court of Justice (ICJ) cases dealing with the delimitation of maritime boundaries. And while they have to fulfil some scientific standards that can generate an agreement between all involved partners, ambiguity remains as to what constitutes adequate data. This signals another line of controversy built into the settlement of UNCLOS: scientific controversies over good enough data and their relation to law.

Finally, clauses in UNCLOS dealing with the continental shelf do not prescribe how to deal with overlapping claims between states. The CLCS are only mandated to deal with the individual submissions and refers to the ICJ and other principles in such cases (article 83; un.org 1982, 56). While geo-science still plays a central role in court disputes, diplomatic controversy could re-enter the settlement more clearly. Denmark, Russia, and Canada have significant overlapping claims in the area, so if all three submissions are to be deemed scientifically valid and hence approved by CLCS, another 
controversy may surface in the shape of a more traditional maritime delimitation issue. It could, however, also lead to a bi- or trilateral settlement following the same template as the Russian-Norwegian Barents Sea Agreement, which, in the words of then President Medvedev stands as a "[...] constructive model of how rival Arctic nations should settle their differences" (Harding 2010).

The Ilulissat Declaration remains the modus vivendi for securing peace between the Arctic states. However, it is also clear from our discussion that the way in which the declaration worked as an act of pre-emptive desecuritization by shifting the issue of sovereign rights to a legal-scientific realm generates new controversies. While it successfully minimizes the risk of horizontal conflict between states, it simultaneously gives way for vertical disputes between the signatory states and the Indigenous peoples of the Arctic, who question the legitimacy behind the alleged right to delineate the Arctic Ocean. Furthermore, the legal-scientific framework embraced by UNCLOS generates its own new controversies. This speaks to a broader concern within desecuritization studies about the nature of normal politics in International Relations. While providing little in terms of a concrete answer, this article has aimed to present an empirical case of how a pre-emptive desecuritization displaces controversy from security to other areas.

\section{Conclusion}

Throughout the Cold War, the Arctic was securitized by the military sector as part of a possible US and USSR military conflict, which would in turn threaten most of the world. While several attempts to de-escalate East-West tension in the Arctic were made, it was not until Gorbachev's speech in 1987 that a desecuritization act was widely acknowledged, paving the way for cooperation. Two decades went with only sparse interest from external actors beyond the region, but a cocktail of climate change, emerging economic opportunities, and geopolitical uncertainty elevated the Arctic on the global political agenda and fueled the A5's expectations of territorial expansion and economic gain. Hardened interstate rhetoric and securitizing attempts by some journalists and academics followed in the wake of Russia's 2007 flag planting on the geographic North Pole. Nine months later, the Ilulissat Declaration was born in direct response to concerns about regional interstate conflict and to downplay securitization attempts, leaving some of the most hawkish observers convinced that an 'Arctic anarchy' was, indeed, called off. In this way, the Ilulissat Declaration pre-emptively desecuritized the issue of sovereign rights in the Arctic Ocean by actively downgrading it, which is the second possible strategy described by Buzan and Wæver $(2003,489)$.

As a case for desecuritization, the Arctic, however, challenges some established conventions within securitization theory. It is state elites that initiate desecuritization and they do so not only through discursive strategies, but also by shifting issues in danger of being securitized to institutional frameworks. If securitization can be seen as a technique of government, then, this is a question of shifting issues from one to other 
techniques of government. Contrary to the democratic ethos of the theory, these shifts in government techniques do not necessarily represent more democratic procedures. Instead, each of these techniques are populated by their own experts and technocrats operating according to logics of right (law) and accuracy (science) that never speak with ambiguous voices, challenging the notion of what normal politics are.

While shifting techniques of government might diminish the danger of securitized relations between states, the shift generates what we defined as a displacement of controversy. Within international law, we have seen controversy over its ontological foundations. Within science, we have seen controversy over standards of science. Each of these are amplified and become more political significant when an issue is securitized via relocation to another technique. While the Ilulissat Declaration has been successful in minimizing the horizontal conflict potential between states, it has simultaneously given way for vertical disputes between the signatory states on the one hand and the Indigenous peoples of the Arctic on the other who question the very understanding of the sovereignty concept and the legitimacy behind the alleged right to delineate territory and claim sovereign rights in the far North. In times with good interstate relations, these voices are easier heard in the regional security discourse. Until CLCS has made the final assessments, such voices may gain even more volume, but if overlapping claims are deemed valid by the CLCS, the final decision will be made by International Court of Justice or via bi-/trilateral agreements, hardened interstate rhetoric, and securitization attempts may resurface to a dominant position on the Arctic security discourse.

\section{Bibliography}

Apple, RW. Jr. (1980). Norwegian in Soviet for Security Talks; First Parley in 15 Years Will Open Today on Tensions at NATO's North Flank in the Arctic Constant Soviet Denunciation Barents Sea the Vital Issue. New York Times. 21 December.

Aradau, C. (2004). Security and the Democratic Scene: Desecuritization and Emancipation. Journal of International Relations and Development, vol. 7(4), pp. 388413.

Associated Press. (2007). Arctic has 'always been Russian': Russian Scientist. CTV News, 7 August. Available at: http://www.ctvnews.ca/arctic-has-alwaysbeen-russian-russian-scientist-1.251703 [Accessed 15 February 2017].

ATS.aq. (1959). The Antarctic Treaty. Secretariat of the Antarctic Treaty. Available at: http://www.ats.aq/documents/ats/treaty_original.pdf [Accessed 15 February 2017].

Balzacq, T., Depauw, S. and Léonard, S. (2015). The Political Limits of Desecuritization: Security, Arms Trade, and the EU's Economic Targets'. In: T. Balzacq 
(ed.). Contesting Security: Strategies and Logics. London: Routledge, pp. 104-121.

Borgerson, S.G. (2008). Arctic Meltdown: The Economic and Security Implications of Global Warming. Foreign Affairs March/ April 2008.

Borgerson, S.G. (2013). The Coming Arctic Boom: As the Ice Melts the Region Heats Up. Foreign Affairs, July/ August.

Bourbeau, P. and Vuori, J.A. (2015). Security, resilience and desecuritization: multidirectional moves and dynamics. Critical Studies on Security, vol. 3(3), pp. 253-268.

Breum, M. (2013). Når Isen Forsvinder - Danmark som stormagt i Arktis, Grønlands rigdomme og kampen om Nordpolen. København: Gyldendal.

Bush, G.W. (2009). National Security Presidential Directive and Homeland Security Presidential Directive, Subject: Arctic Region Policy. The White House. 12 January. Available at:

http://georgewbush-whitehouse.archives.gov/news/releases/2009/01/200901123.html [Accessed 15 February 2017].

Buzan, B., Wæver, O. and J. de Wilde. (1998). Security: a new framework for analysis. Boulder, London: Lynne Rienner Publishers.

Buzan, B., and Wæver, O. (2003). Regions and Powers: The Structure of International Security. Cambridge Studies in International Relations (CSIR). New York: Cambridge University Press.

Buzan, B. and Wæver, O. (2009). Macrosecuritization and security constellations: reconsidering scale in securitization theory. Review of International Studies, vol. 35(2), pp. $253-276$.

Byers, M. (2009). Who Owns the Arctic? Understanding Sovereignty and International Law in the North. Vancouver/Toronto/Berkeley: Douglas \& McIntyre.

Byers, M. (2013). International Law and the Arctic. Cambridge Studies in International and Comparative Law. Cambridge: Cambridge University Press.

Casey, T. (2007). Dailey Press Briefing. U.S. Department of State. 2 August. Available at: http://2001-2009.state.gov/r/pa/prs/dpb/2007/aug/90016.htm [Accessed 15 February 2017].

Chung, A. (2007). The Arctic Cold War. Toronto Star. 12 August. Available at: https://www.thestar.com/news/insight/2007/08/12/the_arctic_cold_war.html [Accessed 10 February 2017].

Dodds, K. (2015). From Ilulissat to Kiruna: managing the Arctic Council and the contemporary geopolitics of the Arctic. In: L.C. Jensen, L and G. Hønneland (eds.). Handbook of the Politics of the Arctic. Cheltenham, UK: Edward Elgar, pp. 375-387.

Ebinger, C.K. and Zambetakis, E. (2009). The Geopolitics of Arctic Melt. International Affairs, vol. 85(6), pp. 1215-1232. 
Financial Times. (2007). Scramble for the Arctic. Financial Times, the Big Read. 19 August. Available at: https://www.ft.com/content/65b9692c-4e6f-11dc-85e70000779fd2ac [Accessed 10 February 2017].

Floyd, R. (2011). Can Securitization Theory be Used in Normative Analysis? Towards a Just Securitization Theory. Security Dialogue, vol. 42(4-5), pp. 427-439.

Gerhardt, H. (2011). The Inuit and Sovereignty: The Case of the Inuit Circumpolar Conference and Greenland. POLITIK, vol. 14(1), pp. 6-14.

Gorbachev, M. (1987). The Speech in Murmansk at the ceremonial meeting on the occasion of the presentation of the Order of Lenin and the Gold Star Medal to the city of Murmansk. Novosti Press Agency, pp. 23-31.

Hansen, L. (2012). Reconstructing Desecuritisation: The Normative-Political in the Copenhagen School and Directions for How to Apply It. Review of International Studies, vol. 38(3), pp. 525-546.

Harding, L. (2010). Russia and Norway resolve Arctic border dispute. The Guardian. 15 September. Available at:

http://www.guardian.co.uk/world/2010/sep/15/russia-norway-arctic-borderdispute [Accessed 15 February 2017].

Hopkins, K. (2008). Fuel prices: Iran missile launches send oil to $\$ 147$ a barrel record. The Guardian. 12 July. Available at: http://www.guardian.co.uk/business/2008/jul/12/oil.commodities [Accessed 15 February 2017].

Hough, P. (2013). International Politics of the Arctic: Coming in from the Cold. Abingdon: Routledge.

Huysmans, J. (1995). Migrants as a security problem: dangers of 'securitizing' societal issues. In: D. Thranhardt and R. Miles (eds.). Migration and European Integration: the dynamics of inclusion and exclusion. London: Pinter, pp. 53-72.

Huysmans, J. (1998). The Question of the Limit: Desecuritisation and the Aesthetics of Horror in Political Realism. Millennium - Journal of International Studies, vol 27(3), pp. 569-589.

Huysmans, J. (2006). The Politics of Insecurity. Fear, Migration and Asylum in the EU. London: Routledge.

Inuit Ataqatigiit. (2015). Inuit Ataqatigiit repræsenteret ved stor Arktis konference. iafolketingimi.dk. 13 November. Available at: http://iafolketingimi.dk/da/inuitataqatigiit-repraesenteret-ved-stor-arktis-konference/ [Accessed 14 February 2017].

ICC. (2009). A Circumpolar Inuit Declaration on Sovereignty in the Arctic. Inuit Circumpolar Council. Available at: http://www.inuitcircumpolar.com/sovereigntyin-the-arctic.html [Accessed 15 February 2017].

Ilulissat Declaration. (2008). Arctic Ocean Conference, Ilulissat, Grønland. 27-29 May. Jacobsen, M. (2015). The Power of Collective Identity Narration: Greenland's Way to a more Autonomous Foreign Policy. In: L. Heininen, H. Exner-Pirot and J. 
Plouffe (eds.). Arctic Yearbook 2015: Arctic Governance and Governing. Akureyri, Iceland: Northern Research Forum, pp. 102-118.

Jacobsen, M. (2015). High North Dialogue 2015 - Interview with Christian Marcussen. The Arctic Institute. March 9. Available at:

http://www.thearcticinstitute.org/high-north-dialogue-2015-interview-withchristian-marcussen/ [Accessed 17 February 2017].

Joyner, C.C. (1991). Ice-covered Regions in International Law. Natural Resources Journal, vol. 31(1), pp. 213-242.

Krauss, C. (2008). Oil Hits $\$ 100$ a Barrel for the First Time. New York Times. 2 January. Available at: http://www.nytimes.com/2008/01/02/business/02cndoil.html?_r=0 [Accessed 15 February 2017].

Macnab, R. (2008). Submarine Elevations and Ridges: wild cards in the poker game of UNCLOS article 76. Ocean Development and International Law, vol. 39, pp. 223-34.

Nature Geoscience. (2009). Dividing the shelves. Nature Geoscience, vol. 2, p. 309.

Roe, P. (2004). Securitization and Minority Rights: Conditions of Desecuritization. Security Dialogue, vol. 35(3), pp. 279-294.

Shadian, J. (2010). From states to polities: Reconceptualising sovereignty through Inuit governance. European Journal of International Relations, vol. 16(3), pp. 485510.

Shaw, M.N. (2003). International Law. Cambridge: Cambridge University Press.

Strandsbjerg, J. (2010) (not published). Interview with Christian Marcussen. 20 September.

Strandsbjerg, J. (2011). Geopolitik, naturlige grænser og 'kartopolitik' i Arktis. POLITIK, vol. 14(1), pp. 51-60.

Strandsbjerg, J. (2012). Cartopolitics, Geopolitics and Boundaries in the Arctic. Geopolitics, vol. 17(4), pp. 818-842.

thestar.com. (2007). Canada must be vigilant about Arctic, Harper says'. The Toronto Star. 2 August. Available at:

http://www.thestar.com/news/2007/08/02/canada_must_be_vigilant_about_arct ic_harper_says.html [Accessed 15 February 2017].

un.org. (1982). United Nations Convention on the Law of the Sea of 10 December 1982, United Nations, Division for Ocean Affairs and the Law of the Sea. Available at:

http://www.un.org/depts/los/convention_agreements/texts/unclos/unclos_e.pdf [Accessed 15 February 2017].

USGS (US Geological Survey). (2008). Circum-Arctic resource appraisal; estimates of undiscovered oil and gas north of the Arctic Circle, U.S. Department of the Interior. Available at: http://pubs.usgs.gov/fs/2008/3049/fs2008-3049.pdf [Accessed 15 February 2017].

Weber, B. (2015). Canada, Denmark should turn Hans Island into a condominium: academics. CBC News. 12 November. Available at: 
http://www.cbc.ca/news/canada/north/canada-denmark-should-turn-hansisland-into-a-condominium-academics-1.3315640 [Accessed 14 February 2017].

Wæver, O. (1989). Security the Speech Act: Analysing the Politics of a Word. (Working paper no. 1989/19). Copenhagen: Centre for Peace and Conflict Research.

Wæver, O. (1995). Securitization and Desecurization. In: R. D. Lipschutz (ed.). On Security. New York: Columbia University Press, pp. 46-86.

Wæver, O. (2000). The EU as a Security Actor. Reflections from a Pessimistic Constructivist on Post-Sovereign Security Orders. In: M. Kelstrup and M. C. Williams (eds.). International Relations Theory and the Politics of European Integration. Power Security and Community. London, Routledge, pp. 250-294.

Åtland, K. (2008). Mikhail Gorbachev, the Murmansk Initiative, and the Desecuritization of Interstate Relations in the Arctic. Cooperation and Conflict, vol. 43(3), pp. 289-311. 